\title{
Inverted Nasal Papilloma: Retrospective Analysis of our Clinical Results
}

\author{
Sedat Aydın,' (1) Hacer Baran, ' (1) Mehmet Gökhan Demir,2 \\ (1) Serdar Ceylan, ${ }^{3}$ (1) Elif Uysal ${ }^{1}$
}

\section{'Department of Otolaryngology, Dr. Lütfi Kırdar Kartal Training and Research Hospital, İstanbul, Turkey \\ ${ }^{2}$ Department of Otolaryngology, Etimesgut State Hospital, Ankara Turkey \\ ${ }^{3}$ Department of Otolaryngology, Centrium Medical Center İstanbul, Turkey \\ Submitted: 15.11.2018 Accepted: 04.02.2019 \\ Correspondence: Sedat Aydın Kartal Dr. Lütfi Kırdar Eğitim Ve Araştırma Hastanesi, KBB Kliniği, İstanbul, Turkey \\ E-mail: sedataydin63@yahoo.com

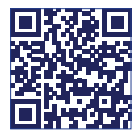 \\ Keywords: Benign tumor; endoscopic sinus surgery; inverted nasal papilloma; nasal obstruction; paranasal sinus.

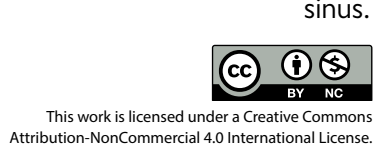

\begin{abstract}
Objective: To evaluate our cases diagnosed with inverted nasal papilloma (INP) and to contribute to the literature on the future surgical and clinical approaches in the light of the results obtained.
\end{abstract}

Methods: In this study, 80 patients who underwent surgical treatment between 2010-2018 in our clinic were evaluated retrospectively. The patients were analysed according to demographic data, complaints, primary region, clinical stage, computed tomography (CT) scores, surgical methods, malign transformation and recurrence.

Results: Of the patients, 65 (8I.25\%) were male, and I5 (18.75\%) were female. The mean age was $53 \pm 12$ years. The most common complaint was unilateral nasal obstruction $(96.2 \%)$. The most common primary site of INP was the lateral nasal wall (52.5\%). Bone erosion was observed in II patients (13.7\%). Of the 74 (92.5\%) patients who underwent endoscopic sinus surgery (ESS), 23 (28.8\%) of them underwent lateral rhinotomy to complete the tumor excision. 9 (I $1.3 \%$ ) patients underwent revision surgery due to recurrence. In 4 (5\%) of the cases, nonkeratinized squamous cell carcinoma was observed.

Conclusion: INPs have been investigated for both their diagnosis and treatment earlier with the introduction of endoscopy into the routine nasal examination. We think that close follow-up of cases is very important, especially because of the high rate of recurrence of these tumors and the transformation to malignancy.

\section{INTRODUCTION}

Rhinosinusal papillomas are divided into three histological types, such as inverted, oncocytic (columnar/cylindric) and exophytic (fungiform). ${ }^{[l]}$ Inverted nasal papilloma (INP) is the most common type of rhinosinusal papilloma with a rate of $70 \%$ and constitutes approximately $0.5 \%$ to $4 \%$ of all sinonasal neoplasms. ${ }^{[2]}$ INPs are benign epithelial tumors characterized by epithelial-stromal invagination, hyperplasia of the nose and paranasal sinus mucosal basal cells. ${ }^{\left[{ }^{[3]}\right.}$

INPs are usually derived from the lateral nasal wall and observed unilaterally. INPs are especially known as the disease of the $5^{\text {th }}$ and $6^{\text {th }}$ decades with male predominance. ${ }^{[3,4]}$ Etiology is still unknown; however, human papillomavirus (especially types $6,1 \mathrm{I}, 16,18$ ) are a potential agent of the neoplasm. ${ }^{[5]}$ In addition, bacterial and viral infections, chronic inflammation, allergens, smoking are thought to play a role in the development of INP. ${ }^{[6]}$
The first complaint of INP patients is usually nasal obstruction. ${ }^{[2]} \mathrm{A}$ multilobulated exophytic lesion in the physical examination may be confused with inflammatory nasal polyps. Therefore, INP should be considered and confirmed by histopathological examination in unilateral nasal polypoid masses. ${ }^{[7]}$

INP is considered as a local aggressive tumor in $2-10 \%$ of cases due to malignant transformation risk and recurrence rate of $12-20 \% .{ }^{[8,9]}$ The treatment of INP is surgical excision. Before the development of endoscopic sinus surgery (ESS) techniques, even if the approach methods, such as transnasal, lateral rhinotomy, midfacial degloving, are used, recently ESS are preferred instead of other surgical techniques. ${ }^{[6]}$ In our study, we aimed to present the surgical methods and results of 80 surgically treated patients who were diagnosed with INP in our clinic with the literature. 


\section{MATERIALS AND METHODS}

In Health Science University Kartal Dr. Lütfi Kirdar Training and Research Hospital Otorhinolaryngology Clinic, information of 80 patients undergoing surgical treatment between the years of 2010-2018 with the diagnosis of INP were analyzed retrospectively. This study was approved by the Ethics Committee of our hospital (895/3307/1009/406). Informed consent was obtained from all participants who enrolled in this study. Demographic data of the patients, such as age, gender, presenting symptoms, previously applied surgical interventions, the presence of additional disease, the anatomical region, stage, applied surgical techniques and recurrence information, were obtained by examining patient files retrospectively. Paranasal sinus CT was performed to evaluate the preoperative tumor prevalence in all patients. Clinical staging of the patients was performed according to Krause classification. ${ }^{[10]}$ As a surgical method, lateral rhinotomy/ medial maxillectomy, ESS and Caldwell-Luc operations were performed.

\section{Statistical analysis}

The mean, standard deviation and minimum-maximum values of the patients were calculated. In the analysis of the relationship between smoking, old surgery, recurrence and malignancy, Fisher's exact test and Pearson chi-square test were used. The significance of statistical results was accepted as $p<0.05$. For statistical analysis, IBM SPSS Statistics for Macintosh, Version 20 (IBM Corp., New York, USA) program was used.

\section{RESULTS}

The ages of 80 patients included in this study ranged from 20 to 83 years, with a mean age of $53( \pm 12)$ years. 65 (81.25\%) of the cases were male and I5 (18.75\%) were female (Table I). The most common complaints were nasal obstruction ( $96.2 \%)$; rhinorrhea $(41 \%)$, headache $(36.2 \%)$, facial fullness $(20 \%)$, hyposmia (18.7\%), epistaxis $(10 \%)$, epiphora (10\%) and hearing loss (7.5\%) followed this (Table 2). Twenty-four (30\%) of the cases had a history of ESS and in 21 (26.25\%) of them, pathological results of previous surgery were nasal polyps. The pathological result was reported as INP in three patients who had ESS applied before externally guided.

In this study, $54 \%$ of the patients had left side and $46 \%$ of the patients had right side lesion. There was no bilateral lesion in any of the cases (Fig. I). When the primary anatomic localizations of the disease were evaluated, the lateral nasal wall was the most common site, with a rate of $68.7 \%$ (55 patients). In 26 (32.5\%) patients, the disease taking his origin from middle meatus and its surroundings, five $(6.25 \%)$ patients from the ethmoid sinus, four $(5 \%)$ patients from the maxillary sinus, two (2.5\%) patients from the inferior concha and one (1.25\%) patients from the septum was detected (Table 3). Rhinosinusitis were present
Table I. Distribution of the patients according to demographic and clinical parameters

\begin{tabular}{lcc}
\hline & $\mathbf{n = 8 0}$ & $\%$ \\
\hline $\begin{array}{l}\text { Gender } \\
\text { Male }\end{array}$ & 65 & 81.25 \\
$\quad$ Female & 15 & 18.75 \\
Age groups (year) & & \\
$20-40$ & 18 & 22.5 \\
$41-60$ & 40 & 50 \\
$61-80$ & 19 & 23.75 \\
$>80$ & 3 & 3,75 \\
Smoking habit & & \\
Yes & 31 & 38.75 \\
No & 49 & 61.25 \\
Associated chronic rhinosinusitis & & \\
Yes & 7 & 8.75 \\
No & 73 & 91.25 \\
Previous surgery & & \\
Yes & 24 & 30 \\
No & 56 & 70 \\
\hline
\end{tabular}

Table 2. Distribution of the patients' complaints

\begin{tabular}{lc}
\hline Complaints & $\%$ \\
\hline Nasal obstruction & 96.2 \\
Rhinorrhea & 41 \\
Headache & 36.2 \\
Fullness of the face & 20 \\
Hyposmia & 18.7 \\
Epistaxis & 10 \\
\hline
\end{tabular}

in $8.75 \%$, nasal polyposis in $12.2 \%$, antrochoanal polyp in $5.5 \%$ of the cases (Table I).

According to the Krause staging system, ${ }^{[10]} 4$ (5\%) of our cases were classified as stage I, $27(33.7 \%)$ were stage 2 , $34(42.5 \%)$ were stage 3 and $15(18.75 \%)$ were classified as stage 4 (Table 4). On CT bone remodelling was detected in $33 \%$ of the cases and bone erosion was observed in II (13.75\%) of our cases (Fig. 2).

The open technique with lateral rhinotomy was performed to complete the tumor excision in $23(28.8 \%)$ of $74(92.5 \%)$ cases that we started the operation with ESS. When we analyzed the distribution of these cases
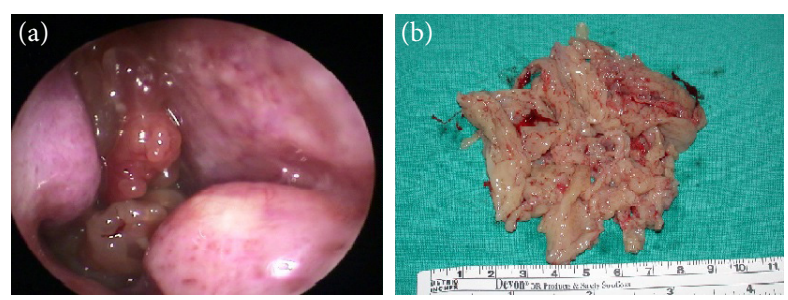

Figure 1. Clinical endoscopic view (a) of and endoscopically excised (b) inverted nasal papilloma. 
Table 3. Inverted nasal papilloma's' origin of our cases

\begin{tabular}{lcc}
\hline & $\mathbf{n = 8 0}$ & $\%$ \\
\hline Lateral nasal wall & 42 & 52.5 \\
Middle meatus & 26 & 32.5 \\
Ethmoid sinus & 5 & 6.25 \\
Maxillary sinus & 4 & 5 \\
Inferior concha & 2 & 2.5 \\
Nasal septum & $\mathrm{I}$ & 1.25 \\
\hline
\end{tabular}

Table 4. Distribution of our patients according to Krouse staging system

\begin{tabular}{lcc}
\hline & $\mathbf{n = 8 0}$ & $\%$ \\
\hline Stage 1 & 4 & 5 \\
Stage 2 & 27 & 33.75 \\
Stage 3 & 34 & 42.5 \\
Stage 4 & 15 & 18.75 \\
\hline
\end{tabular}

according to the Krause staging system, ${ }^{[10]}$ we identified 0 patients as stage $\mathrm{I}$, five patients as stage 2 , nine patients as stage 3 and nine patients as stage 4 . Stage 3 and four cases were statistically different from stage I and 2 . Since maxillary sinus walls cannot be dominated endoscopically in $6(7.5 \%)$ patients, Caldwell-Luc operations were performed in addition to ESS. Revision surgery was performed in nine (11.25\%) cases due to recurrence. The mean recurrence time was 8.6 years in cases. None of the recurrent cases had undergone open surgery previously. All nine patients underwent ESS previously, but three of the patients undergoing revision ESS had a history of ESS performed previously. Pathological diagnosis of three patients was reported as a nasal polyp in the first ESS. According to the Krause staging system, ${ }^{[10]}$ five of recurrent cases were classified as stage 2, four of recurrent cases were stage 3 . There were not any stage I

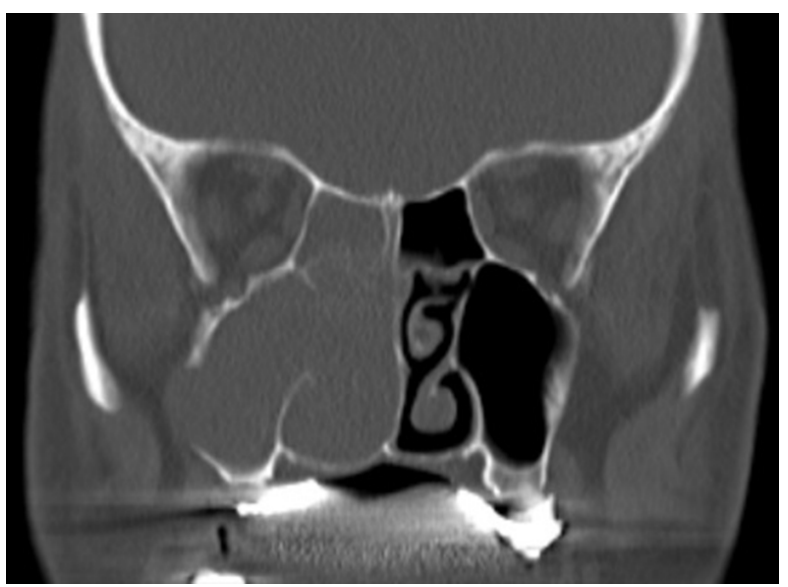

Figure 2. Coronal view of Paranasal Sinus CT: Soft tissue mass filling the right nasal cavity completely, bone erosion of the ethmoidal cells and bone defect in the lateral wall of the maxillary antrum. and 4 in these cases. Stage 2 and 3 cases were statistically different from stage I and 4 . There were no statistically significant differences between stage 2 and stage 3 in recurrent cases. Non-keratinized squamous cell carcinoma (SCC) was observed in four (5\%) cases. While SCC was detected in 3 of these cases during the diagnosis of INP, the other patient was diagnosed as SCC by biopsy performed during the follow-up period 6 months after the first operation.

\section{DISCUSSION}

INP are benign epithelial tumors that develop by stromal invagination of the mucosal epithelium in the nasal cavity and paranasal sinus; however, they are well-monitored lesions in the clinic due to their local aggressive course and the possibility of recurrence and malignant transformation. ${ }^{[3, I I]}$ Although INP can be seen at all ages, it is most commonly seen in the 5 th and 6th decades. INP is observed more frequently in male patients. ${ }^{[3,4]}$ The findings in our study were consistent with the previous data and the mean age was 53 and the $M: F$ ratio was $4.33 .^{[12-14]}$

The most common complaint in patients is the nasal obstruction. In addition, additional complaints, such as rhinorrhea, headache, epistaxis and anosmia, can be observed. The symptoms are not specific, but unilateral signs and symptoms should be considered for INP. ${ }^{[2,14]}$ In our study, the most common symptom was a nasal obstruction, with a frequency of $96.2 \%$ similar to other studies. Rhinorrhea (4I\%), headache $(36.2 \%)$, facial fullness $(20 \%)$, hyposmia (18.7\%), epistaxis (10\%), epiphora (10\%) and hearing loss (7.5\%) followed this complaint.

In the endoscopic examination, the INP is more rigid and opaque than the inflammatory polyps. However, INP can be observed in the deep of inflammatory polyps. This may make it difficult to suspect INP in the endoscopic examination. ${ }^{[14]}$ Although INP is often seen as a unilateral mass, the bilateral lesion has been defined between $4-9 \%$ in the studies. ${ }^{[7,14]}$ It has been suggested that bilateral nasal involvement arises from the infiltration of the septum into the nasal meatus. ${ }^{[15,16]}$ In our study, the bilateral lesion was not observed in any patient.

Imaging methods are important concerning the localization of the tumor, its prevalence, its relationship with adjacent structures and selection of the surgical intervention to be performed. ${ }^{[17]}$ On the CT, INPs appear as heterogeneous intense contrast-enhancing masses in soft tissue density. Remodelling of the bone is characteristic and manifests itself with the calcification in the tumor, erosion and sclerotic changes in $43 \%$ of cases. ${ }^{[17,18]}$ In our study, CT was routinely requested from all patients suspected of INP before the operation. In our series, bone remodelling was detected in $33 \%$ of the cases. We think that this particular image detection will be important in deciding the surgical method. Definitive diagnosis in INP is determined by biopsy, but in some cases, false negatives may occur because these lesions can be observed together with benign 
polyps. However, the preoperative biopsy is considered important in the exclusion of malignancy. ${ }^{[19]}$

Although INP mostly originates from the lateral nasal wall and the maxillary medial wall, it may also originate from the frontal sinus, sphenoid sinus or nasal septum. ${ }^{[4,20]}$ In our study, the lateral nasal wall was the most common localization, with $52.5 \%$ incidence.

The classification system described by Krause in 2000 is accepted in INP staging. ${ }^{[10]}$ In the study performed by Çomoğlu et al., ${ }^{[13]}$ the majority of the patients (78.8\%) were staged as T3. Krause et al. and in the articles published by Lawson et al.," ${ }^{[12]} 91 \%$ and $88 \%$ were staged as T3 and $\mathrm{T} 4$, respectively. In our study, four (5\%) of our cases were classified as stage I, 27 (33.75\%) were stage 2, 34 (42.5\%) were stage 3 and 15 (18.75\%) were classified as stage 4 . Unlike other studies, stage 2 intensity of the patients was more. This situation can be explained by the increasing importance of ESS in the unilateral sinus pathologies and the possibility of early diagnosis with the developing technological parameters.

The gold standard in treatment is surgical resection of the tumor. Although various methods, such as lateral rhinotomy, medial maxillectomy, and Caldwell-Luc, have been applied, ESSs are generally used with the development of technical facilities. ${ }^{[16,20]}$ In our study, the open technique with lateral rhinotomy was performed to complete the tumor excision in 23 (28.75\%) of 74 (92.5\%) cases that we started the operation with the ESS. Stage 3 and 4 groups were statistically significant in the Krause staging of 23 patients who underwent open technique lateral rhinotomy. In our opinion, it may be more meaningful to start operation with open technique in advanced stages. In the anterior and lateral wall involvement of the maxillary sinus, ESS can be performed in combination with Caldwell-Luc. ${ }^{[2]}$ In our study, Caldwell-Luc intervention was added to ESS in six cases $(7.5 \%)$.

Localized recurrence of INP is $0-24 \% .{ }^{[22]}$ In our study, revision surgery was performed in nine (II.25\%) patients due to recurrence. All nine patients underwent ESS previously, but three of the patients undergoing revision ESS had a history of ESS performed previously. Stage 2 and 3 cases were statistically different from stage $I$ and 4.

The rate of conversion to INP malignancy was reported as $9.1 \% .^{[8,9]}$ In our study, non-keratinized SCC was observed in four $(5 \%)$ of the cases. While SCC was detected in three of these cases at the time of diagnosis of INP, one of them was observed in the follow-up period of six months after the first operation.

\section{CONCLUSION}

As a result, although the INP is a benign epithelial tumor, it should be closely monitored considering the risk of malignant transformation and recurrence. Endoscopic endonasal surgery has improved the treatment rates of INP as new surgical instruments and devices are developed.
Financial Disclosure

The authors declared that this study had received no financial support.

Ethics Committee Approval

Approved by the local ethics committee.

Informed Consent

Retrospective study.

Peer-review

Internally peer-reviewed.

Authorship Contributions

Concept: S.A., M.G.D., H.B., E.U.; Design: S.A., M.G.D., H.B., E.U.; Supervision: S.A., M.G.D., H.B., E.U.; Data: S.A., E.U.; Analysis: S.A.; Literature search: S.A.; Writing: S.A., E.U.; Critical revision: S.A.

Conflict of Interest

None declared.

\section{REFERENCES}

1. WHO Classification of Tumours. Barnes L, Eveson JW, Reichart P, Sidransky D, editors. Pathology and genetics of head and neck tumours. Lyon: IARC Press; 2005. p. 28-32.

2. Hyams VJ. Papillomas of the nasal cavity and paranasal sinuses. A clinicopathological study of 315 cases. Ann Otol Rhinol Laryngol 1971;80:192-206. [CrossRef]

3. Buchwald C, Franzmann MB, Tos M. Sinonasal papillomas: a report of 82 cases in Copenhagen County, including a longitudinal epidemiological and clinical study. Laryngoscope 1995;105:72-9. [CrossRef]

4. Zhao L, Li CW, Jin P, Ng CL, Lin ZB, Li YY, et al. Histopathological features of sinonasal inverted papillomas in Chinese patients. Laryngoscope 2016;126:E141-7. [CrossRef]

5. Buchwald C, Lindeberg H, Pedersen BL, Franzmann MB. Human papilloma virus and P53 expression in carcinomas associated with sinonasal papillomas: a Danish epidemiological study 1980-1998. Laryngoscope 2001;111:1104-10. [CrossRef]

6. Mortuaire G, Arzul E, Darras JA, Chevalier D. Surgical management of sinonasal inverted papillomas through endoscopic approach. Eur Arch Otorhinolaryngol 2007;264:1419-24. [CrossRef]

7. Gravello W, Gaini RM. Incidence of inverted papillomas in recurrent nasal polyposis. Laryngoscope 2006;116:221-3. [CrossRef]

8. Lund VJ, Stammberger H, Nicolai P, Castelnuovo P, Beal T, Beham A, et al. European position paper on endoscopic management of tumours of the nose, paranasal sinuses and skull base. Rhinol Suppl 2010;22:1-143.

9. Mirza S, Bradley PJ, Acharya A, Stacey M, Jones NS. Sinonasal inverted papillomas: recurrence, and synchronous and metachronous malignancy. J Laryngol Otol 2007;121:857-64. [CrossRef]

10. Krause JH. Development of a staging system for inverted papilloma. Laryngoscope 2000;110:965-8. [CrossRef]

11. Sukenik MA, Casiano R. Endoscopic medial maxillectomy for inverted papillomas of the paranasal sinuses: value of the intraoperative endoscopic examination. Laryngoscope 2000;110:39-42. [CrossRef]

12. Lawson W, Patel ZM. The evolution of management for inverted papilloma: An analysis of 200 cases. Otolaryngol Head Neck Surg 2009;140:330-5. [CrossRef]

13. Çomoğlu Ş, Öztürk E, Enver N, Öztürk İE, Çelik M, Polat B, et al. Inverted Papilloma: A Comprehensive Clinic Analysis. J Ist Faculty Med 2016;79:157-62. [CrossRef] 
14. Díaz Molina JP, Llorente Pendas JL, Rodrigo Tapia JP, Alvarez Mar$\cos \mathrm{C}$, Obeso Agüera S, Suárez Nieto C. Inverted sinonasal papillomas. Review of 61 cases. Acta Otorrinolaringol Esp 2009;60:402-8.

15. McCary WS, Gross CW, Reibel JF, Cantrell RW. Preliminary report: endoscopic versus external surgery in the management of inverting papilloma. Laryngoscope 1994;104:415-9. [CrossRef]

16. Reh DD, Lane AP. The role of endoscopic sinus surgery in the management of sinonasal inverted papilloma. Curr Opin Otolaryngol Head Neck Surg 2009;17:6-10. [CrossRef]

17. Chawla A, Shenoy J, Chokkappan K, Chung R. Imaging Features of Sinonasal Inverted Papilloma: A Pictorial Review. Curr Probl Diagn Radiol 2016;45:347-53. [CrossRef]

18. Head CS, Sercarz JA, Luu Q, Collins J, Blackwell KE. Radiographic as- sessment of inverted papilloma. Acta Otolaryngol 2007;127:515-20.

19. Lawson W, LeBenger J, Peter J, Bernard MB, Hugh F, Biller MD, et al. Inverted papillomas: an analysis of 87 cases. Laryngoscope 1989;99:117-24. [CrossRef]

20. Krause JH. Endoscopic treatment of inverted papilloma: safety and efficacy. Am J Otolaryngol 2001;22:87-99. [CrossRef]

21. Lian F, Juan H. Different endoscopic strategies in the management of recurrent sinonasal inverted papilloma. J Craniofac Surg 2012;23:e44-8. [CrossRef]

22. Gras-Cabrerizo JR, Montserrat-Gili JR, Massegur-Solench $H$, León-Vintró X, De Juan J, Fabra-Llopis JM. Management of sinonasal inverted papillomas and comparison of classification staging systems. Am J Rhinol Allergy 2010;24:66-9. [CrossRef]

\section{İnverted Nazal Papillomalı Hastalarımızın Klinik Sonuçlarının Geriye Dönük Analizi}

Amaç: Kliniğimizde inverted nazal papilloma (INP) tanısı almış olguların retrospektif olarak değerlendirilmesi, elde edilen sonuçlar ışı̆̆ında sonraki cerrahi ve klinik yaklaşımlar konusunda literatüre katkıda bulunmaktır.

Gereç ve Yöntem: Kliniğimizde 20I0-20I8 arasında INP tanısı alarak cerrahi tedavi uygulanan 80 hasta geriye dönük olarak değerlendirildi. Hastalar demografik verileri, başvuru şikayeti, kaynaklandığı primer bölge, klinik evresi, bilgisayarlı tomografi (BT) skorları, uygulanan cerrahi yöntemler, malign transformasyon ve rekürrens açısından değerlendirildi.

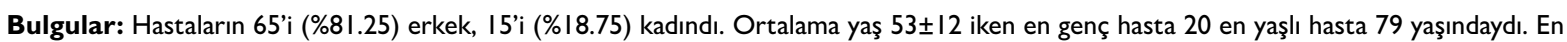
sık görülen şikayet tek taraflı burun tıkanıklığı (\%96.2) idi. İkinci sırada başağrısı (\%4I) izlendi. İNP'nin görüldüğü en sık primer bölge lateral nazal duvar (\%52.5) iken sırasıyla orta meatus (\%32.5) ve ethmoid sinüs (\%6.25) de izlendi. Olgularımızın II (\%।3.7) kadarında BT'de kemik erozyonu izlendi. Endoskopik sinüs cerrahisi (ESC) ile başladığımız 74 (\%92.5) olgumuzun 23'üne (\%28.8) tümör eksizyonunu tamamlamak için lateral rinotomi ile açık teknik uygulandı. Rekürrens nedeniyle dokuz (\%। I.3) olgumuza revizyon cerrahi uygulandı. Olguların dördünde (\%5) nonkeratinize skuamöz hücreli karsinom izlendi.

Sonuç: İnverted nazal papillomalar endoskopinin rutin nazal muayeneye girmesiyle hem tanınmalarını hem de tedavilerini daha erken hale getirmiştir. Önceleri uyguladı̆̆ımız klasik açık cerrahi müdahaleler yerini fonksiyonel ESC'ye bırakmıştır. Özellikle bu tür tümörlerin yüksek oranda rekürrensi ve maligniteye transformasyon göstermesi sebebiyle olguların yakın takibinin çok önemli olduğunu düşünüyoruz.

Anahtar Sözcükler: Benign tümör; burun tıkanıklığı; endoskopik sinüs cerrahisi; inverted nazal papillom; paranazal sinüs. 